\title{
PRETERM BIRTHS IN A RESOURCE CONSTRAINED SETTING: SOCI- OBIOLOGIC RISK FACTORS AND PERINATAL OUTCOMES
}

\author{
A.A AKINTAYO ${ }^{1}$, J.O AWOLEKE ${ }^{1}$, E.O OGUNDARE ${ }^{2}$, O.S OLATUNYA ${ }^{2}$ and O.P ADULOJU ${ }^{1}$ \\ ${ }^{1}$ Department of Obstetrics and Gynaecology, and ${ }^{2}$ Department of Paediatrics, Ekiti State University, Ado- \\ Ekiti, Ekiti State, Nigeria
}

DOI: http://dx.doi.org/10.4314/gmj.v49i4.6

Corresponding Author: Dr. Akinyemi A. Akintayo

Conflict of Interest: None declared

\section{SUMMARY}

Background: To determine maternal risk factors and perinatal outcomes of preterm births in south-western Nigeria.

Methods: A retrospective study of preterm and term deliveries in a tertiary hospital in Nigeria. The delivery records were reviewed and case files of preterm births were identified and retrieved. Perinatal outcomes were determined by review of the postnatal and special care baby unit records. Multivariate logistic regression was carried out to determine factors independently associated with preterm births. Adjusted odds ratios and confidence intervals were determined.

Results: The preterm birth rate was 5.7\%. Prelabour rupture of membranes was the leading cause of preterm birth, while a third of them were unexplainable. Age $>35 y$ rs (AOR 2.16(1.36-3.42)), the unbooked status (AOR 2.52(1.76-3.61)), Previous history of preterm delivery (AOR 6.41(2.48-16.60)), pre-labour rupture of membranes (AOR 11.08(6.01-18.56)), antepartum haemorrhage (AOR 10.91(4.94-24.09)), multiple gestations (AOR 32.23(13.07-79.50)) and hypertension in pregnancy(AOR6.42(3.79-10.88)) were independently associated with preterm delivery. Low birthweight, asphyxia, neonatal intensive care unit admission and perinatal mortality were common among preterm births. The perinatal mortality rate among the preterm neonates was $14.5 \%$.

Conclusion: Preterm birth remains a significant cause of perinatal deaths. Strategies addressing potentially modifiable risk factors will reduce the incidence and improve the perinatal outcomes associated with preterm births.

Keywords: preterm delivery, prematurity, perinatal mortality, Nigeria.
E-mail: akinyemiakintayo@yahoo.co.uk

\section{INTRODUCTION}

Preterm delivery, defined as birth before 37 weeks of gestation $^{1}$ is a major obstetric and perinatal concern worldwide. Approximately $9.6 \%$ of all deliveries are preterm with low income countries contributing over $90 \%$ of such births, ${ }^{2}$ and as a result carrying a greater burden of deaths and disabilities attributed to preterm births. The reported incidence of preterm birth varies between $5.8 \%$ and $11.1 \%$ in Nigeria. ${ }^{3-6}$ Preterm birth is the leading cause of perinatal morbidity and mortality worldwide. ${ }^{7}$ Despite the fact that global perinatal mortality rates have been on the decline in the last decade, the decline is less prominent in sub-Saharan Africa. Preterm births account for $70 \%$ of neonatal deaths and up to $75 \%$ of neonatal morbidity. ${ }^{8}$ About $50 \%$ of neonatal deaths in Nigeria are related to preterm birth. ${ }^{3}$ Of the survivors, $10 \%$ to $15 \%$ have significant handicaps. ${ }^{8,9}$ Severe morbidities such as respiratory distress syndrome, intraventricular haemorrhage, bronchopulmonary dysplasia and necrotizing enterocolitis are far more common in pre-term than in term infants. ${ }^{10,11}$

These morbidities are not limited to the immediate post-delivery period, as long-term sequelae such as cerebral palsy, visual and hearing impairment are also more common in preterm infants. Preterm birth in itself is a risk factor for a repeat preterm birth in subsequent pregnancies. ${ }^{12}$ Preterm delivery is caused by multiple pathologic processes, ${ }^{13,14}$ have a long subclinical phase, and may result from complex gene-environment interactions. Preterm births can occur spontaneously, may follow preterm prelabour rupture of membranes or may be medically indicated in the face of complications. Identified risk factors include low socioeconomic status, HIV in pregnancy, previous preterm delivery, infections and infestations, polyhydramnios, multiple pregnancies, prelabour rupture of membranes and antepartum haemorrhage. ${ }^{3-6,15}$ A significant proportion of preterm births are unexplained. ${ }^{16}$ 
Attempts made to reduce preterm births are critical in reducing perinatal mortality. The identification of women at risk of preterm delivery is essential, since there are evidence based methods of reducing preterm delivery in selected cases. Cervical cerclage ${ }^{17}$ and the use of progesterone ${ }^{18}$ are of proven benefits.

The social and emotional cost of perinatal morbidity and mortality associated with prematurity is certainly enormous. It accounts for $35 \%$ and $10 \%$ of healthcare spending for infants and children respectively in United States of America ${ }^{19}$. Many developing countries are unable to cope with the healthcare costs associated with managing neonates that are born preterm due to the cost and low availability of neonatal intensive care units, coupled with irregular power supply. ${ }^{6}$ Preterm birth is a major public health issue. In accordance with the MDG 4 which emphasizes the reduction in child mortality by two-thirds, research efforts addressing the aetiology and the determinants of outcome of preterm births will create a pathway into achieving this goal especially as prematurity is a major contributor to infant mortality. This study was conducted to identify socio-biologic risk factors for preterm births and determine outcomes of preterm births in Ekiti State, Nigeria. This would enable early identification of modifiable risk factors for preterm birth among women at risk of preterm birth, and close monitoring of such patients with the aim of commencement of evidenced based prevention of preterm birth.

\section{METHODS}

This retrospective case-controlled study was done between 1st January 2010 and 31st December, 2012 at Ekiti State University Teaching Hospital (EKSUTH), Ado - Ekiti, Ekiti State, Southwest Nigeria. EKSUTH is the only tertiary healthcare institution located in the capital of Ekiti State, South-West Nigeria. About 1500 deliveries take place in Ekiti State University Teaching Hospital annually. The hospital serves as a referral centre for primary and secondary healthcare facilities located in Ekiti State and other neighboring towns and communities in Ondo, Kwara and Kogi States. The patients accessing care in EKSUTH are from a mix of urban and sub-urban settlements.

The delivery records of the EKSUTH were reviewed. The names and hospital numbers of all the women who had pre-term births were selected. For every preterm delivery, two women who had term deliveries within the period of study were randomly selected as controls. The case notes were retrieved and relevant information extracted.
Maternal characteristics such as age, weight, marital status, educational status and social status using classification by Olusanya et $\mathrm{al}^{20}$ were extracted. Reproductive characteristics such as parity, booking status, previous history of induced abortion, previous history of pre-term delivery, history of antenatal complications as well as multiple gestations were also noted.

Perinatal outcomes consisted of birth weight, APGAR scores at 1 and 5 minutes, special care baby unit admission and early neonatal complications. The information was retrieved by a review of the post-natal and special care baby unit records. All deliveries between estimated gestational ages of 28 weeks and before 37 weeks in EKSUTH during the review period were considered in this review. They served as the cases.

All deliveries between estimated gestational ages of 37 weeks and 41 weeks and 6 days within the study period were eligible as controls. A random sample of these was retrieved using a random list of case file numbers generated from the hospital's records department after excluding the preterm births and births after $\geq 42$ weeks. These served as controls. Deliveries before 28 weeks gestation or/at 42 weeks and beyond were excluded from the study. Gestational ages were determined by calculation from the first day of the last menstrual period and verified with the report of an early ultrasound scan.

Births without vital information or record of gestational age were excluded. Ethical approval for the study was obtained from the ethics and research committee of EKSUTH. The data obtained were analyzed using SPSS version 17. Frequency distributions and percentages were generated. Chi square tests were used to determine univariate association between preterm births and maternal risk factors and to compare perinatal outcomes between preterm and term births. Strength of association was estimated using the odds ratio and the corresponding 95\% confidence interval. Multivariate analysis was applied to factors that showed significant association with preterm births on univariate analysis to identify independent risk factors for preterm birth. Statistical significance was set at p-values $<0.05$.

\section{RESULTS}

There were a total of 4347 deliveries within the study period. Two hundred and forty-eight were preterm, giving a preterm birth rate of $5.7 \%$. There was inadequate information for six cases and therefore 242 cases together with 484 controls were used in analysis. Majority $(70.2 \%)$ of the preterm births followed spontaneous preterm labour, $36.4 \%$ of which was associated with preterm PROM, while $29.8 \%$ of the cases were 
medically indicated, the leading indication being hypertensive disorders of pregnancy. The mean gestational age at delivery for the cases was $33.84 \pm 2.27$ weeks and the mean birth weight was $2.11 \pm 2.27 \mathrm{~kg}$, while the mean gestational age and mean birth weight for the controls were $39.26 \pm 1.35$ weeks and $3.16 \pm 0.45 \mathrm{~kg}$ respectively. Majority of the women studied were between ages 20 and 35 years. Most of them also had tertiary education and were in the higher socioeconomic groups. Majority of the patients had antenatal care in the index pregnancy. The association between age $>35$ years (AOR 2.16; 95\% CI: 1.36-3.42) and the unbooked status (AOR 2.52; 95\% CI: 1.763.61) with preterm delivery were statistically significant. The parity of the woman, socioeconomic status and level of education were however not significantly related to likelihood of a preterm delivery. (Table 1)

Table 1 Sociodemographic Characteristics of the patients

\begin{tabular}{|c|c|c|c|c|c|c|}
\hline Factors & $\begin{array}{l}\text { Preterm } \\
\mathrm{N}=242(\%)\end{array}$ & $\begin{array}{l}\text { Term } \\
\text { N=484 (\%) }\end{array}$ & $\begin{array}{l}\text { Crude Odds Ratio } \\
\text { (95\% CI) }\end{array}$ & p-value & Adjusted Odds Ratio & p-value \\
\hline $\begin{array}{l}\text { Age } \\
\leq 35 \\
>35\end{array}$ & $\begin{array}{r}199(82.2) \\
43(17.8)\end{array}$ & $\begin{array}{l}439(90.7) \\
45(9.3)\end{array}$ & $2.11(1.34-3.10)$ & 0.001 & $2.16(1.36-3.42)$ & 0.001 \\
\hline $\begin{array}{l}\text { Parity } \\
\text { Primiparous } \\
\text { Multiparous }\end{array}$ & $\begin{array}{l}85(35.1) \\
157(64.9)\end{array}$ & $\begin{array}{l}177(36.6) \\
307(63.4)\end{array}$ & $1.06(0.77-1.147)$ & 0.702 & & \\
\hline $\begin{array}{l}\text { Education } \\
\text { Secondary or less } \\
\text { Tertiary }\end{array}$ & $\begin{array}{l}110(45.5) \\
132(54.5)\end{array}$ & $\begin{array}{l}174(36.0) \\
310(64.0)\end{array}$ & $1.48(1.08-2.03)$ & 0.013 & $1.06(0.75-1.50)$ & 0.746 \\
\hline $\begin{array}{l}\text { Booking Status } \\
\text { Booked } \\
\text { Unbooked }\end{array}$ & $\begin{array}{l}137(56.6) \\
105(43.4)\end{array}$ & $\begin{array}{l}372(76.9) \\
112(23.1)\end{array}$ & $2.54(1.82-3.54)$ & $<0.001$ & $2.52(1.76-3.61)$ & $<0.001$ \\
\hline $\begin{array}{l}\text { Socioeconomic Status } \\
1-2 \\
3-5\end{array}$ & $\begin{array}{l}165(68.2) \\
77(31.8)\end{array}$ & $\begin{array}{l}341(70.5) \\
143(29.5)\end{array}$ & $0.90(0.64-1.25)$ & 0.53 & & \\
\hline
\end{tabular}

Table 2 Obstetric factors affecting preterm births

\begin{tabular}{|c|c|c|c|c|c|c|}
\hline Factor & $\begin{array}{l}\text { Preterm } \\
\mathrm{N}=\mathbf{2 4 2}(\%)\end{array}$ & $\begin{array}{l}\text { Term } \\
\mathrm{N}=484(\%) \\
\end{array}$ & $\begin{array}{l}\text { Crude Odds Ratio } \\
(95 \% \text { CI })\end{array}$ & p-value & $\begin{array}{l}\text { Adjusted Odds Ratio } \\
(95 \% \text { CI) }\end{array}$ & p-value \\
\hline $\begin{array}{l}\text { Previous Preterm delivery } \\
\text { No } \\
\text { Yes }\end{array}$ & $\begin{array}{l}212(87.6) \\
30(12.4)\end{array}$ & $\begin{array}{l}476(98.3) \\
8(1.7) \\
\end{array}$ & $8.41(3.80-18.67)$ & $<0.001$ & $6.41(2.48-16.60)$ & $<0.001$ \\
\hline $\begin{array}{l}\text { PROM } \\
\text { No } \\
\text { Yes } \\
\end{array}$ & $\begin{array}{l}154(63.6) \\
88(36.4)\end{array}$ & $\begin{array}{l}454(93.8) \\
30(6.2)\end{array}$ & $8.65(5.50-13.60)$ & $<0.001$ & $11.08(6.61-18.56)$ & $<0.001$ \\
\hline $\begin{array}{l}\text { Multiple Pregnancy } \\
\text { No } \\
\text { Yes }\end{array}$ & $\begin{array}{l}178(73.6) \\
64(27.4)\end{array}$ & $\begin{array}{l}478(98.8) \\
6(1.2)\end{array}$ & $28.64(12.19-67.31)$ & $<0.001$ & $32.23(13.07-79.50)$ & $<0.001$ \\
\hline $\begin{array}{l}\text { Hypertension } \\
\text { No } \\
\text { Yes }\end{array}$ & $\begin{array}{l}184(76.0) \\
58(24.0)\end{array}$ & $\begin{array}{l}448(92.6) \\
36(7.4)\end{array}$ & $3.92(2.50-6.15)$ & $<0.001$ & $6.42(3.79-10.88)$ & $<0.001$ \\
\hline $\begin{array}{l}\text { Antepartum Hemorrhage } \\
\text { No } \\
\text { Yes }\end{array}$ & $\begin{array}{l}218(90.1) \\
24(9.9)\end{array}$ & $\begin{array}{l}473(97.7) \\
11(2.3) \\
\end{array}$ & $4.73(2.27-9.84)$ & $<0.001$ & $10.91(4.94-24.09)$ & $<0.001$ \\
\hline $\begin{array}{l}\text { Previous Surgical abortion } \\
\text { No } \\
\text { Yes }\end{array}$ & $\begin{array}{l}158(65.3) \\
84(34.7)\end{array}$ & $\begin{array}{l}328(67.8) \\
156(32.2)\end{array}$ & $1.12(0.69-1.29)$ & 0.503 & & \\
\hline $\begin{array}{l}\text { Fetal sex } \\
\text { Female } \\
\text { Male }\end{array}$ & $\begin{array}{l}130(53.7) \\
112(46.3) \\
\end{array}$ & $\begin{array}{l}231(47.7) \\
253(52.3) \\
\end{array}$ & $0.78(0.58-1.07)$ & 0.128 & & \\
\hline
\end{tabular}

Table 2 highlights the association between the woman's past obstetric history and the presence of some obstetric complications in the index pregnancy with preterm delivery.
Previous history of preterm delivery (AOR 6.41; 95\%CI: 2.48-16.60), prelabour rupture of membranes (AOR 11.08; 95\%CI :6.61-18.56), antepartum haemorrhage (AOR 10.91; 95\%CI: 4.94-24.09), multiple ges- 
tations (AOR 32.23; 95\%CI: 13.07-79.50) and hypertension in pregnancy(AOR 6.42;95\%CI: 3.79-10.88) were significantly associated with preterm delivery. The fetal sex and previous history of surgical abortion were not significantly related to preterm delivery.

The perinatal outcomes of the preterm delivered babies were compared to that of the controls in table 3. Low birth weight infants (birthweight less than $2.5 \mathrm{~kg}$ ) were found to be significantly higher among the preterm delivered babies. The likelihood of admission into the special care baby unit, APGAR scores less than seven at 1 and 5 minutes were significantly more among the preterm babies. Perinatal mortality was higher among the preterm neonates ( 22 stillbirths and 13 early neonatal deaths) compared to the controls (11 stillbirths and 1 early neonatal death).

Table 3 Comparism of neonatal outcomes of preterm and term Babies

\begin{tabular}{|c|c|c|c|c|}
\hline & $\begin{array}{l}\text { Preterm } \\
\mathrm{N}=\mathbf{2 4 2 ( \% )}\end{array}$ & $\begin{array}{l}\text { Term } \\
\mathrm{N}=\mathbf{4 8 4}(\%)\end{array}$ & $\begin{array}{l}\text { Odds Ratio } \\
(95 \% \text { CI) }\end{array}$ & p-value \\
\hline $\begin{array}{l}\text { Birthweight } \\
<2.5 \mathrm{~kg} \\
\geq 2.5 \mathrm{~kg}\end{array}$ & $\begin{array}{l}173(71.2) \\
69(29.8)\end{array}$ & $\begin{array}{l}26(5.4) \\
458(94.6)\end{array}$ & $\begin{array}{l}44.17(27.23- \\
71.64)\end{array}$ & $<0.001$ \\
\hline $\begin{array}{l}\text { SCBU* admission } \\
\text { (Total } \mathrm{N}=693 \text { ) } \\
\text { No } \\
\text { Yes }\end{array}$ & $\begin{array}{l}101(45.9) \\
119(54.1)\end{array}$ & $\begin{array}{r}412(87.1) \\
61(12.9)\end{array}$ & $\begin{array}{l}7.96(5.46- \\
11.61)\end{array}$ & $<0.001$ \\
\hline $\begin{array}{l}\text { APGAR Score at } \\
1 \text { min(Total } \\
\mathrm{N}=693 \text { ) } \\
<7 \\
\geq 7\end{array}$ & $\begin{array}{l}58(26.4) \\
162(73.6) \\
\end{array}$ & $\begin{array}{l}64(13.5) \\
409(86.5)\end{array}$ & $\begin{array}{l}.29(1.54- \\
3.41)\end{array}$ & $<0.001$ \\
\hline $\begin{array}{l}\text { APGAR Score at } \\
5 \mathrm{~min} \text { (Total } \\
\mathrm{N}=693 \text { ) } \\
<7 \\
\geq 7\end{array}$ & $\begin{array}{l}21(9.5) \\
199(90.5)\end{array}$ & $\begin{array}{l}13(2.7) \\
460(97.3)\end{array}$ & $\begin{array}{l}3.73(1.83- \\
7.62)\end{array}$ & $<0.001$ \\
\hline $\begin{array}{l}\text { Still births } \\
\text { Still births } \\
\text { Livebirths }\end{array}$ & $\begin{array}{l}22(9.1) \\
220(90.9)\end{array}$ & $\begin{array}{l}11(2.3) \\
473(97.7)\end{array}$ & $\begin{array}{l}4.00(1.97- \\
8.11)\end{array}$ & $<0.001$ \\
\hline $\begin{array}{l}\text { Perinatal Outcome } \\
\text { Stillbirth/ENND** } \\
\text { Birth with survival } \\
\text { beyond 1week }\end{array}$ & $\begin{array}{l}35(14.5) \\
207(85.5)\end{array}$ & $\begin{array}{l}12(2.5) \\
472(97.5)\end{array}$ & $\begin{array}{l}6.65(3.39- \\
13.07)\end{array}$ & $<0.001$ \\
\hline
\end{tabular}

$* \mathrm{SCBU}=$ special care baby unit. $* * \mathrm{ENND}=$ early neonatal death.

Prelabour rupture of membranes (36.4\%) was the leading identifiable cause of preterm delivery from our study; this was followed by multiple gestations $(27.3 \%)$, hypertensive disorders of pregnancy $(24 \%)$ and previous preterm deliveries (12.4\%). About 3 out of every $10(29.8 \%)$ preterm deliveries followed either induction of labour or emergency caesarean sections, while others followed spontaneous preterm labour.
Other identifiable causes of preterm delivery identified from our study include antepartum haemorrhage, infections and infestations, polyhydramnios, congenital anomalies in the fetus, maternal medical conditions other than hypertension. There was no identifiable risk factor for preterm delivery in $36.4 \%$ of the cases reviewed.

\section{DISCUSSION}

Preterm delivery and prematurity remains a major concern as demonstrated from our study. We found a preterm births rate of $5.7 \%$. Advanced maternal age and lack of antenatal care were significant sociodemographic contributors. Obstetric factors identified as risks for preterm delivery were previous history of preterm delivery, multiple gestations, prelabour rupture of membranes, antepartum haemorrhage and hypertension in pregnancy. The incidence of low birth weight, asphyxia and perinatal mortality was significantly higher in the preterm babies. Prelabour rupture of membranes was the leading cause of preterm births, while there were no identifiable risk factors in about a third of cases.

The observed incidence of $5.7 \%$ found from our study is comparable to $5.8 \%$ reported by Chike $\mathrm{Obi}^{3}$ in Ilorin but less than $6.9 \%$ and $8.5 \%$ reported from hospitalbased studies in $\mathrm{Kano}^{6}$ and Calabar ${ }^{4}$ respectively. Reports from other developing countries revealed a higher incidence ranging between $11.1 \%$ and $57 \%$. ${ }^{21-23}$ Higher values, $12.7-15 \%$ have been reported in developed countries ${ }^{24,25}$ this is however mostly related to medically indicated preterm delivery.

The relationships between maternal sociobiological characteristics and preterm delivery have been widely discussed and varying opinions have been reported. Previous studies evaluating the association between maternal age and preterm birth have revealed varying reports. Previous studies ${ }^{3,21}$ reported a significant association between teenage pregnancy and preterm delivery, other authors reported lack of association between maternal age and preterm birth. ${ }^{4,6}$ We found a higher likelihood of preterm birth among women greater than 35 years. This finding is similar to the reports of Rouget et $\mathrm{al}^{26}$ and Hoffman et $\mathrm{al}^{27}$ who also found an association between the older pregnant woman and preterm birth. The relationship between advanced maternal age and preterm delivery is probably related to the higher likelihood of medical conditions that may necessitate early delivery among this age group. 
Low parity has been reported by previous studies to be associated with preterm delivery. ${ }^{3,19}$ Parity was not found to be significantly associated with preterm delivery in this study, this is in congruence with the findings from studies done by Omole-Ohonsi ${ }^{6}$ in northern Nigeria. Low socioeconomic class and level of education did not show significant statistical relationship to preterm births. These findings compare favorably with previous studies ${ }^{4,26}$ but vary from the report of Ezechi ${ }^{5}$ and Omole-Ohonsi ${ }^{6}$ where education and socioeconomic class showed significant association with preterm delivery. The decision to seek for healthcare including obstetric care is believed to be easier for the more educated patient and patients in the higher socioeconomic cadre. Previous reports have related low socioeconomic status with stress which has been found to be a trigger for preterm labour and delivery. ${ }^{6,28}$ Our study however did not support a relationship between level of education or socioeconomic class of the patient and preterm birth.

The campaign for antenatal care and supervised delivery still needs to be intensified. Women who were not booked for antenatal care in the hospital were more likely to have a preterm delivery. The number of antenatal visits has been reported to influence the likelihood of preterm delivery. ${ }^{22}$ The lack of antenatal care mitigates against the chance to identify risks and provide appropriate interventions towards prevention of preterm delivery and its attendant perinatal outcome in the antenatal period.

The relationship between multiple gestation and preterm delivery has been established from previous studies, ${ }^{5,29}$ a finding reinforced by this study. This is related to early onset of uterine contractions due to overdistension and the association of multiple pregnancy with other factors like polyhydramnios, antepartum haemorrhage, prelabour rupture of membranes and preeclampsia all of which may necessitate early delivery.

The likelihood of preterm delivery in women who have had a previous preterm delivery is significantly higher than others who have not had a previous preterm delivery. This is probably due to the persistence of the cause of the previous preterm delivery in such patients. This is in keeping with the findings of previous Nigerian studies $^{4,15,29}$ and Rouget ${ }^{26}$ in France. Prelabour rupture of membranes was found to be a significant risk factor for preterm delivery from our study. This was similar to the report of Ezechi ${ }^{29}$ and Kempe ${ }^{16}$ but at variance with the findings of Omole-Ohonsi ${ }^{6}$ which showed no significant association.
There have been conflicting opinions on the relationship between previous surgical abortion and preterm delivery. Studies conducted by Mokuolu et $\mathrm{al}^{15}$ and Etuk et $\mathrm{al}^{4}$ revealed a significant association between previous surgical abortion and preterm delivery, while Omole-Ohonsi ${ }^{6}$ reported no association. Our research revealed no significant association between previous surgical abortion and preterm delivery. This is probably related to the recent use of manual vacuum aspiration in conducting surgical induced abortion compared to the previous practice of dilatation and curettage. The process of dilatation is associated with damage to the cervical architecture thus increasing the risk of cervical incompetence in subsequent pregnancies; this is less likely when the procedure is performed by manual vacuum aspiration.

With respect to perinatal outcomes, the incidence of low birth weight babies is significantly higher in the preterm births than in the term babies. This is not surprising because the birth weight is directly related to the period of gestation. The weight at birth is an indicator of a newborn's chances for survival, growth, longterm health and psychosocial development. ${ }^{30}$

The likelihood of asphyxia and perinatal mortality are significantly higher among the preterm babies. It is expected that the incidence of perinatal morbidities and mortality decreases with increasing gestational age at delivery. ${ }^{31}$ Additionally, the risk of respiratory distress syndrome is significant among preterms particularly before the gestational age of 34 weeks. Due to the higher incidence of low birth weight fetuses, and higher risk of asphyxia, it is not surprising that the incidence of special care baby unit admission was significantly higher among the preterm deliveries.

Given that $14.5 \%$ of preterm births resulted in perinatal deaths, attempts to identify those with higher risks of premature delivery are an important step towards reducing perinatal mortality. Facilities for intensive care of the preterm neonate are scarce and expensive in resource strained settings like ours, while the long term care of babies with lifelong neurodevelopmental deficits usually from asphyxia, neonatal sepsis or hyperbilirubinaemia are virtually non-existent in Nigeria.

The use of ultrasound assessment of the cervical length to identify women at risk of preterm labour is limited and cannot be applied to all women in our setting. It is therefore imperative, to identify those with risks based on the available history. 
This would enable referral of patients with such risks from the peripheral centres and also helps the tertiary facilities prepare for the intensive care of such babies.

It would also provide a platform for the administration of progesterone which has been shown by studies to prevent preterm birth in women at risk. Our study therefore provides insight on the epidemiologic profile of women with preterm birth and emphasizes the need for intensive attention to these women in order to curtail the burden of preterm birth and its consequence on the society.

\section{REFERENCES}

1. Challis JRG. Characteristics of parturition. In: Creasy RK, Resnik R, editors. Maternal fetal medicine. 4th ed. Philadelphia: WBSaunders; 1999. p. 484-97.

2. Beck S, Wojdyla D, Say L, Betran AP, Merialdi $\mathrm{M}$, Requejo JH et al. The worldwide incidence of preterm birth: a systematic review of maternal mortality and morbidity. Bull World Health Organ 2010;88:31-8.

3. Chike-Obi U. Preterm Delivery in Ilorin: multiple and teenage pregnancies as major aetiological factors. West Afr J Med. 1993; 12:228-30

4. Etuk SJ,Etuk JS, Oyo-Ita AE Factors Influencing the incidence of preterm birth in Calabar, Nigeria. Niger J Physiol Sci 2005; 20:63-8

5. Ezechi OC, David AN, Gab-Okafor CV, Ohwodo $\mathrm{H}$, Oladele DA, Kalejaiye OO et al . Incidence of and socio-biologic risk factors for spontaneous preterm birth in HIV positive Nigerian women. BMC Pregnancy Childbirth. 2012; $12: 93$

6. Omole-Ohonsi A, Attah RA. Risk factors of preterm deliveries at Aminu Kano Teaching Hospital, Kano;Nigeria. SAJMS 2012; 1: 3-10

7. Goldenberg RL, Culhane JF, Lams JD, Romero R. Epidemiology and causes of preterm birth. Lancet 2008, 371:75-84.

8. Wen SW, Smith G, Yang Q, Walker M. Epidemiology of preterm birth and neonatal outcome. Semin Fetal Neonatal Med. 2004;9: 429-35.

9. Ehrenhaft PM, Wagner JL, Herdman RC. Changing prognosis for very low birth weight infants. Obstet Gynecol 1989;74:528.

10. Saigal S, Stoskopf B, Streiner D, Boyle M, Pinelli J, Paneth N,Goddeeris J. Transition of extremely low-birth-weight infants from adolescence to young adulthood: comparison with normal birthweight controls. JAMA 2006; 295: 667-675.

11. Marlow N, Wolke D, Bracewell MA, Samara M, for the EPICure Study Group. Neurologic and developmental disability at six years of age after ex- tremely preterm birth. $N$ Eng $J$ Med 2005; 352: 919.

12. Adams MM, Elam-Evans LD, Wilson HG, Gilbertz DA. Rates of and factors associated with recurrence of preterm delivery. JAMA 2000;283:1591-6.

13. Romero R, Mazor M, Munoz H, Gomez R, Galasso M, Sherer DM. The preterm labor syndrome. Ann N Y Acad Sci 1994;734:414-29.

14. Macones GA, Parry S, Elkousy M, Clothier B, Ural SH, Strauss JF III. A polymorphism in the promoter region of $\mathrm{TNF}$ and bacterial vaginosis: preliminary evidence of gene-environment interaction in the etiology of spontaneous preterm birth. Am J Obstet Gynecol 2004;190:1504-8; discussion 3A.

15. Mokuolu OA, Abdul IF, Adesiyun O. Maternal factors associated with early spontaneous singleton preterm delivery in Nigeria. Trop J Obstet Gynaecol 2002; 19: 32-35.

16. Kempe A, Wise PH, Barkan SE, Sappenfield WM, Sachs B, Gort-maker SL, et al. Clinical determinants of the racial disparity in very low birth weight. $N$ Engl J Med 1992;327:969-73.

17. Simcox R, Seed PT, Bennett P, Teoh TG, Poston $\mathrm{L}$, Shennan AH. A randomized controlled trial of cervical scanning vs history to determine cerclage in women at high risk of preterm birth(CIRCLE trial). Am J Obstet 2012;206:e1-9.

18. DeFranco EA, O'Brien JM, Adair CD, Lewis DF, Hall DR, Fusey S et al. Vaginal progesterone is associated with a decrease in risk for early preterm birth and improved neonatal outcome in women with a short cervix: a secondary analysis from a randomized, double-blind, placebo-controlled trial. Ultrasound Obstet Gynecol 2007;30:697-705.

19. ACOG technical Bulletin. Preterm labour. Int $J$ Gynaecol Obstet. 1995; 50:303-13.

20. Olusanya O, Okpere E, Ezimokhai E. The importance of social class in voluntary fertility control in developing countries. $W$ Afr $J$ Med 1985;4:205-7.

21. Balaka B, Baeta S, Agbere AD, Boko K, Kessie K, Assimadi K. Risk Factors associated with prematurity at the university Hospital of Lome, Togo. Bull Soc Pathol Exot. 2002 Nov; 95:280-3

22. Chiabi A, Mah EM, Mvondo N, Nguefack S, Mbuagbaw L, Kamga KK et al. Risk factors for premature births: A cross-sectional analysis of hospital records in a Cameroonian health facility. Afr J Reprod Health 2013; 17: 77-83.

23. da Fonseca EB, Bittar RE, Carcalho MH, Zugaib M. prophylactic administration of progesterone by vaginal suppository to reduce the incidence of 
spontaneous preterm birth in women at increased risk: a randomized placebo-controlled boubleblind study. Am J Obstet Gynecol 2003; 188: 41924

24. Hamilton BE, Mini no AM, Martin JA, Kochanek KD,Strobino DM, Guyer B. Annual summary of vital statistics:2005. Pediatrics 2007; 119: 345360.

25. Steer P. The epidemiology of preterm labour. BJOG 2005; 112:1-3.

26. Rouget F, Lebreton J, Kadhel P, Monfort C, Bodeau-Livinec F, Janky E et al. Medical and sociodemographic risk factors for preterm birth in a French carribean population of African descent. Matern Child Health J 2103;17:1103-1111

27. Hoffman MC, Jeffers S, Carter J, Duthely L, Cotter A, Gonzalez-Quintero VH. Pregnancy at or be- yond age 40years is associated with an increased risk of fetal death and other adverse otcomes. Am J Obstet Gynecol. 2007; 196: e11-3.

28. Ancel PY. Preterm labour: pathophysiology, risk factors and outcomes. J Gynaecol Obstet Biol Reprod 2002; 31(7 suppl):5s10-21.

29. Ezechi OC, Makinde ON, Kalu BE, Nnatu SN. Risk factors for preterm delivery in south-western Nigeria. J Obstet Gynaecol 2003; 23:387-91

30. Bale JR, Stoll BJ, Lucas AO (eds) Improving birth outcomes: meeting the challenge in the developing world, 2003. The National Academics Press, Washington DC]

31. Olusanya BO, Solanke OA. Maternal and neonatal profile of late preterm survivors in a poorly resourced country J Mat Fetal Neonat Med 2012; 25:346-352. 